\title{
Pilot-scale lanthanide precipitation from sulfate-based spent Ni-MH battery leachates: thermodynamic based choice of operating conditions
}

\author{
Margot Zielinski ${ }^{1,2}$, Laurent Cassayre ${ }^{1}$, Nicolas Coppey ${ }^{2}$, Béatrice Biscans ${ }^{1}{ }^{\text {* }}$ \\ 1 Laboratoire de Génie Chimique, Université de Toulouse, CNRS, INPT, UPS, Toulouse, France. \\ 2 Société Nouvelle d'Affinage des Métaux (S.N.A.M.), Viviez, France. \\ *Corresponding author: beatrice.biscans@toulouse-inp.fr
}

\section{Supplementary Information}

Proportion of the element remaining in solution at the end of the experiment [\%]

\section{Molar ratio (Na:REs) Temp.}

\begin{tabular}{cccccccc} 
& & Ni & Al & Co & Fe & Mn & Zn \\
$(0.8: 1)$ & $60^{\circ} \mathrm{C}$ & 96.0 & 94.6 & 97.4 & 98.1 & 97.0 & 95.0 \\
$(1.7: 1)$ & $60^{\circ} \mathrm{C}$ & 95.5 & 97.2 & 99.3 & 96.2 & 96.7 & 91.1 \\
$(3.2: 1)$ & $60^{\circ} \mathrm{C}$ & 98.6 & 95.6 & 99.2 & 98.7 & 98.4 & 98.3 \\
$(3.2: 1)$ & $40{ }^{\circ} \mathrm{C}$ & 96.4 & 96.1 & 94.4 & 92.6 & 94.5 & 94.6 \\
$(3.2: 1)$ & $25^{\circ} \mathrm{C}$ & 99.0 & 95.5 & 97.7 & 96.0 & 97.0 & 96.6 \\
\hline
\end{tabular}

Table SI.1. Proportion of the metallic elements remaining in solution after $1 \mathrm{~h}$ of precipitation (batch and semi-batch period) by the addition of a $2.87 \mathrm{M} \mathrm{Na}_{2} \mathrm{SO}_{4}$ solution. Precipitation experiments were carried out at $25^{\circ} \mathrm{C}<T<60^{\circ} \mathrm{C}$ and $(0.8: 1)<(N a: R E E s)$ molar ratio $<(3.2: 1)$ 